\title{
PATI UMBI SUWEG TERMODIFIKASI SEBAGAI BIOSORBEN PENYERAP ION TIMBAL
}

\author{
Ajeng Yulianti Dwi Lestari ${ }^{1)}$, Muhammad Fachmi Kurniawan ${ }^{2}$, Mentari Ferdini Siregar ${ }^{3)}$ \\ Jurusan Teknik Kimia, Fakultas Teknologi Industri, Universitas Islam Indonesia ${ }^{1,2,3)}$, \\ Jl Kaliurang KM 14,5 Sleman, Yogyakarta, 55584 \\ Email :aydlestari@uii.ac.id ${ }^{l}$
}

\begin{abstract}
Novel adsorbents are succesfully manufactured from Amorphophallus campanulatus (Porang or Suweg or Elephant Foot Yam or Foot Yam) starch. The experiment focused on detailing those morphologies and chemical bonds. Analysis with FTIR and SEM showed that PTM sample is the best adsorbent which has most stable of chemical bonding and also has more pores that influence lead adsorption phenomena.
\end{abstract}

Keywords : Elephant Foot Yam, Starch, Adsorbent, Pb(II) Sorption.

\section{PENDAHULUAN}

Setiap industri pasti menghasilkan limbah pada akhir proses produksinya. Limbah industri tersebut dapat berbentuk cair, gas ataupun padat akan mencemari lingkungan jika tidak dikelola dengan baik. Salah satu limbah cair beracun dan berbahaya (B3) adalah limbah cair yang mengandung logam berat sehingga dalam penangannya harus dilakukan proses adsorpsi untuk mengurangi kadar logam berat di dalamnya.

Adsorben untuk menyerab limbah logam berat B3 antara lain : karbon aktif, zeolit dan resin penukar ion. Kelemahan dari adsorben konvensional tersebut adalah keberlanjutannya dimana adsorben tersebut kurang ramah lingkungan serta akan menjadi limbah anorganik yang juga berdampak pada lingkungan. Maka dipandang perlu untuk melakukan sebuah alternatif proses berupa subtitusi penggunaan adsorben konvensional ke penggunaan adsorben biomassa. Adsorben berbasis biomassa dinilai lebih unggul dari asorben konvensional dari sisi keramahan lingkungannya.

Disamping itu, adsorben berbasis biomassa juga memiliki keekonomisan tinggi serta berkemampuan adsorpsi yang tidak kalah dengan adsorben konvensional yang sudah ada (O’Connell dkk; 2008).
Adsorben biomassa dapat dibuat dari biomassa yang memiliki pati dan selulosa yang tinggi karena ada ikatan hidroksil, karboksil yang reaktif dimana secara alamiah dapat menjerab atau mengikat ion logam berat tersebut (Ma dkk; 2015).

Pembuatan adsorben alami yang sudah berjalan, yaitu dengan memanfaatkan singkong, kentang dan jagung sebagai bahan bakunya dinilai akan mengalami hambatan perkembangannya di Indonesia pada khususnya. Sebab ketiga macam bahan baku tersebut merupakan tanaman pangan pokok dan alternatif masyarakat sehingga di khawatirkan akan terjadi benturan kebutuhan. Di sisi lain, ada tanaman yang mengandung pati yang tinggi yang bukan merupakan tanaman pangan alternatif yang keberadaannya melimpah di Indonesia. Tanaman tersebut adalah umbi suweg. Suweg sebagai tanaman yang memiliki kandungan polisakarida berpotensi dapat dijadikan bahan baku adsorben alami penyerap limbah karena kandungan glukosa dan mannosanya memiliki ikatan hidroksil yang kuat yang bersifat dapat menyerap kation (Taritat dkk; 2012, Gautam dkk; 2014). Penelitian yang mengkaji tentang kemampuan umbi suweg ini untuk dijadikan adsorben masih sangat baru dan terbatas (Harmayani dkk; 2014). 
Disamping itu, proses karakterisasi fisik awal adalah menjadi kunci utama dalam memulai pembuatan adsorben. Adsorben yang baik dapat dilihat dari pengaruh sifat karakteristiknya terhadap proses adsorbsinya yang berupa: morfologi, ikatan kimia, serta proses pembuatannya. Oleh sebab itu, tujuan dari penelitian ini adalah mengkaji karakteristik suweg sebagai adsorben biomassa baru dan menilai kemampuannya dalam mengadsorpsi salah satu jenis limbah logam berat, yaitu timbal $(\mathrm{Pb})$.

\section{METODOLOGI PENELITIAN \\ 2.1. Alat dan Bahan}

Bahan baku yang digunakan dalam penelitian ini yaitu umbi suweg yang tumbuh liar di Kabupaten Ngawi, Jawa Timur. Pati diisolasi dengan menggunakan metode fisis yaitu dengan mengekstraksi umbi suweg segar dengan menggunakan akuades. Proses pembuatan pati terporikan menggunakan akuades dan etanol dengan penanganan suhu. Proses pembuatan pati terporikan yang dimodifikasi membutuhkan etanol dan asam sitrat. Alat yang digunakan dalam penelitian ini adalah peralatan kaca, oven, freezer, set alat uji karakteristik yang meliputi FTIR (Fourier Transform Infra Red Spectrofotometer), SEM (Scanning Electron Microscope) dan AAS (Atomic Absorption Spectrofotometer.

\subsection{Tahapan Penelitian}

Suweg yang dipakai adalah umbinya yang berwarna kuning muda. Langkah pertama adalah mengupas kulit umbi hingga bersih kemudian memotong umbi menjadi bagian kecil - kecil sama besar. Potongan umbi kemudian dicuci sampai tidak ada sisa tanah yang menempel kemudian disimpan di wadah yang steril.

Isolasi pati dari umbi suweg dilakukan dengan proses mekanis yang dimulai dengan memarut semua umbi menjadi parutan yang lebih kecil. Setiap $2 \mathrm{~kg}$ umbi dicuci dengan air $1 \mathrm{~L}$ setelah itu dilakukan penyaringan agar umbi terpisah dari air perasannya. Air perasan kemudian di diamkan selama 12 jam dan endapan putih (pati) yang dihasilkan diambil lalu dikeringkan kemudian disimpan di wadah yang steril.

Proses pembuatan pati yang terporikan mengikuti metode yang dipublikasikan oleh Chang dkk (2011). Lima gram pati suweg yang sudah didapatkan pada tahap sebelumnya dicampur dengan $100 \mathrm{~mL}$ akuades dan kemudian dipanaskan pada suhu $90^{\circ} \mathrm{C}$ selama 30 menit untuk membentuk gelatin pati. Campuran kemudian di dinginkan selama 3 hari pada freezer bersuhu $5^{\circ} \mathrm{C}$ hingga gel pati terbentuk. Gel pati yang terbentuk kemudian dipotongpotong kotak - kotak $(1 \mathrm{~cm} \mathrm{x} 1 \mathrm{~cm} \times 1 \mathrm{~cm})$ dan kemudian dibekukan kembali selama 12 jam. Pati gel kemudian direndam pada etanol selama 2 jam. Pati kemudian dikeringkan pada suhu $50^{\circ} \mathrm{C}$ selama 3 jam untuk menghilangkan kadar etanol.

Pati terporikan (PT) akan dimodifikasi dengan menggunakan asam sitrat mengikuti metode yang dilakukan oleh Ma dkk (2015). Langkah awal adalah melarutkan asam sitrat dan pati terporikan ke dalam etanol selama 12 jam pada suhu ruangan. Pati kemudian dikeringkan pada suhu $110^{\circ} \mathrm{C}$ selama 4 jam di dalam oven. Pati yang sudah kering kemudian direndam lagi pada cairan etanol untuk memastikan bahwa asam sitrat terlarutkan dan kemudian dikeringkan dengan suhu ruangan.

Masing - masing dari biosorben yang sudah dibuat kemudian diuji karakteristiknya, yaitu: ikatan kimia di dalam adsorben dengan menggunakan FTIR dan morfologi dengan menggunakan SEM.

\section{HASIL DAN PEMBAHASAN}

\subsection{Karakterisasi Adsorben}

Pati umbi

campunalatus di isolasi dengan menggunakan metode konvensional dengan menggunakan metode pengendapan dari umbi basahnya. Umbi suweg basah dikupas, dicuci kemudian diparut dan diperas airnya. Endapan putih yang ada di dasar air perasan umbi tersebut yang diambil sebagai pati biasa (PB). Ogungbenle (2007) menyebutkan bahwa ada langkah alternatif dalam pengisolasian pati dari umbinya yaitu dengan 
proses ekstraksi dengan menggunakan pelarut heksena - methanol - kloroform. Pati yang dihasilkan menunjukkan kualitas yang berbeda, hasil isolasi metode konvensional lebih putih dibandingkan dengan hasil yang dengan menggunakan proses ekstraksi. Hanya saja belum diukur kandungan pati dengan metode konvensional sebagai perbandingan.

Adsorben yang digunakan untuk penelitian ini ada 3, yaitu: adsorben dari pati suweg biasa (PB), adsorben dari pati suweg yang terporikan (PT) dan adsorben pati terporikan yang dimodifikasi (PTM). Pati umbi Amorphophallus campanulatus diporikan dengan metode mekanis dengan perlakuan suhu. Metode inipun dinilai sangat sederhana dan mudah untuk diaplikasikan. Hasil dari proses pemorian ini adalah morfologi adsorben yang lebih amorf dan tidak seragam permukaannya. PT kemudian dimodifikasi dengan menggunakan asam sitrat sesuai dengan metode yang disampaikan oleh Chang dkk (2011).

Proses analisis dengan menggunakan FTIR merk FTIR Thermo Nicolet Avatar 360 dilaksanakan di Laboratorium Instrumen MIPA Terpadu Universitas Islam Indonesia. Hasil analisis FTIR dari ketiga adsorben, yaitu: PB, PT, PTM disajikan pada Gambar 1 berikut. Gambar 1 menunjukan overlay dari ketiga adsorben dimana menunjukkan ikatan kimia yang ada pada sampel. Garis hitam menunjukkan spektra untuk PB, abuabu untuk PT dan biru untuk PTM. Pada PB, PT dan PTM sama - sama menunjukkan adanya ikatan kimia pada garis gelombang $3.400 \mathrm{~cm}^{-1}, 2.750 \mathrm{~cm}^{-1}, 2.300 \mathrm{~cm}^{-1}, 1.800$ $\mathrm{cm}^{-1}, 1.000 \mathrm{~cm}^{-1}$ dan $500-1.000 \mathrm{~cm}^{-1}$ dimana menunjukkan adanya ikatan $\mathrm{O}-\mathrm{H}$ pada panjang gelombang $3.500-2.500 \mathrm{~cm}^{-1}$, ikatan $\mathrm{C}=\mathrm{O}$ pada panjang gelombang $1.800-1.840$ $\mathrm{cm}^{-1}$, ikatan $\mathrm{C}-\mathrm{O}$ pada panjang gelombang $1.000-1.300 \mathrm{~cm}^{-1}$ serta ikatan alifatik C-N $1.220-1.020 \mathrm{~cm}^{-1}$ (Stuart; 2009). Perbedaan dari ketiga sampel adalah pada \% transimitasinya, dimana menunjukkan kekuatan ikatan kimia yang ada pada sampel. Untuk ikatan O-H, sampel PB, PT dan PTM sama-sama berada pada $\%$ transimitasi rendah, yaitu $20 \%$. Hal ini menunjukkan bahwa sebagian besar ikatan pada ketiga sampel adalah ikatan hidroksil $\mathrm{O}-\mathrm{H}$, dimana ini adalah parameter adsorpsi untuk proses penyerapan air. Untuk ikatan $\mathrm{C}=\mathrm{O}$ pada panjang gelombang antara 1.800-1.840 cm-1 terjadi perbedaan pada \% transmitasinya untuk PB sebesar 34\%, PT 32\% sedangkan PTM adalah 30\%. Hal ini menunjukkan bahwa semakin banyak perlakuan modifikasi akan merubah struktur ikatan kimia pada senyawa murninya. Proses modifikasi pati juga mempengaruhi jumlah kekuatan ikatan C-N pada PB dan PT dimana terlihat pada peak peak yang terjadi pada PTM lebih banyak dan cenderung tajam. Maka dapat ditarik kesimpulan bahwa proses modifikasi pati dengan menggunakan asam sitrat dapat merubah kualitas ikatan kimia yang ada pati murni.

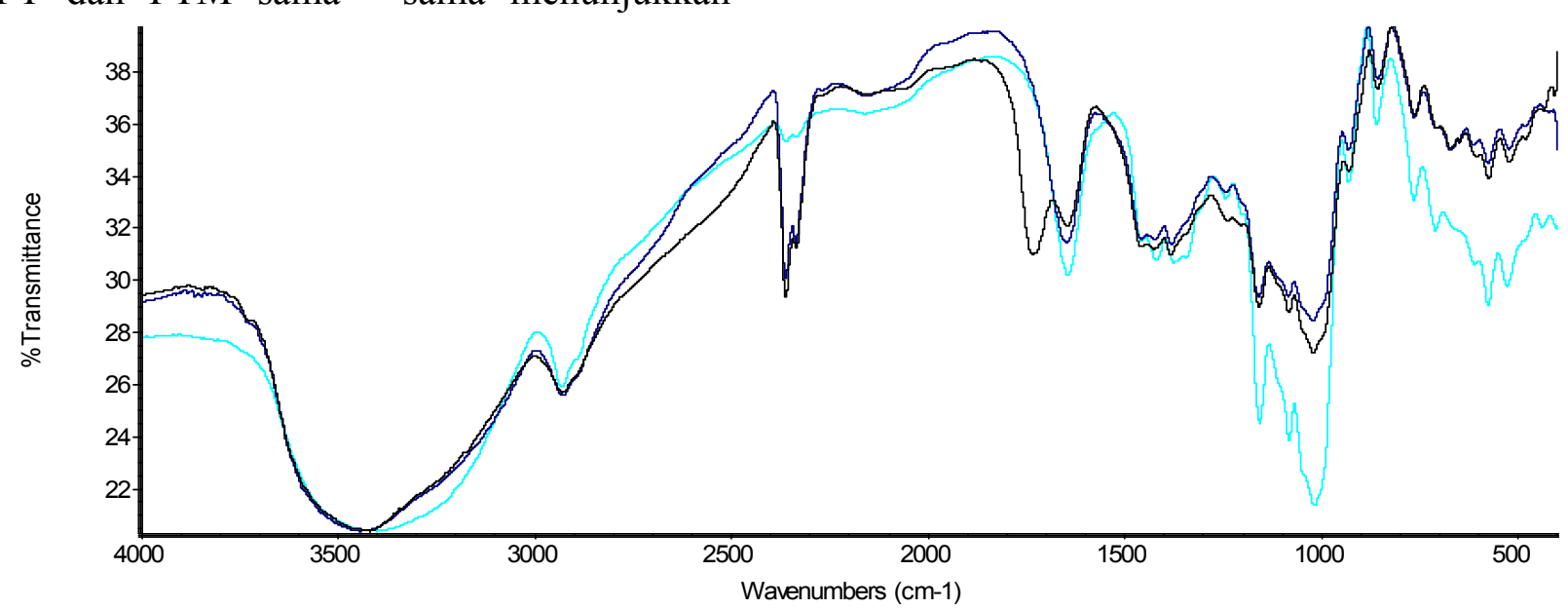

Gambar 1. Spektra FTIR PB, PT, PTM. 
Spektra FTIR ini kemudian dibandingkan dengan hasil analisis FTIR pada pati umbi yang sama tetapi dengan cara

isolasi yang berbeda, seperti gambar 2 berikut ini.

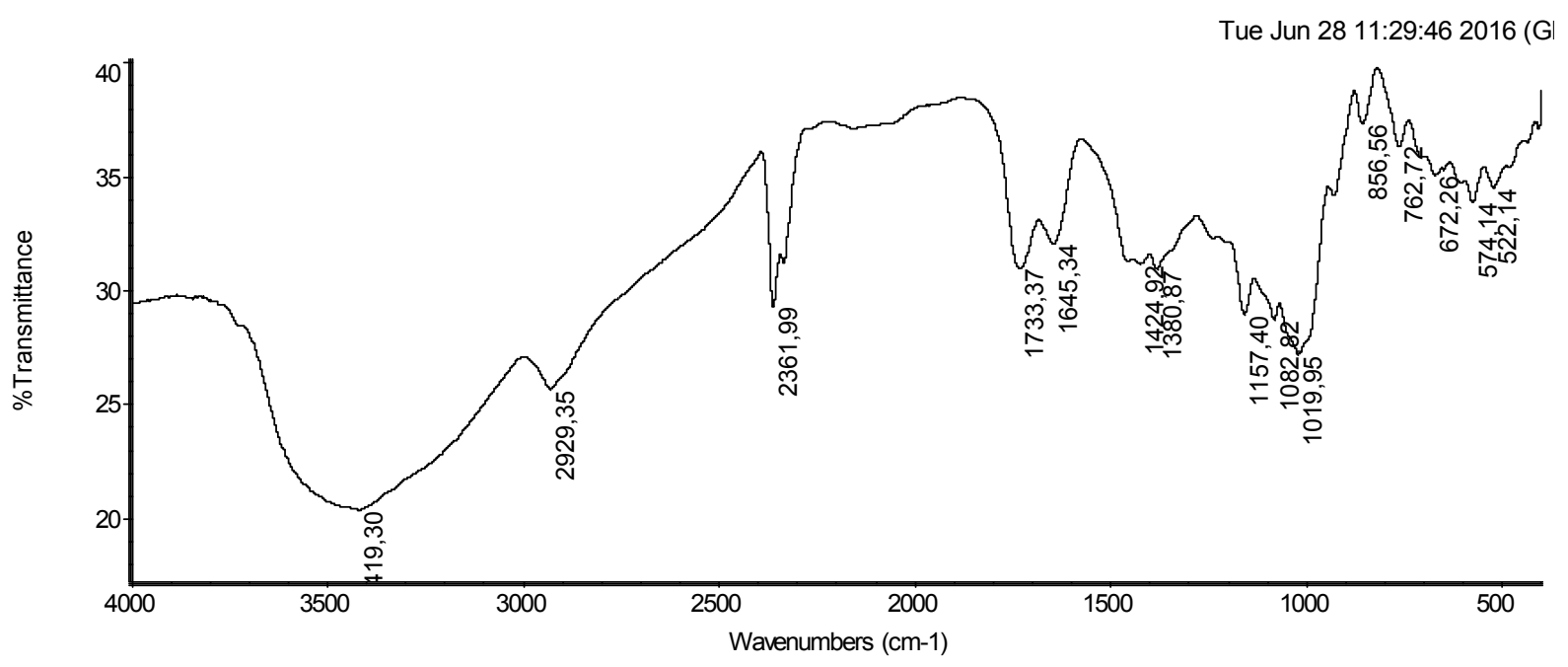

Gambar 2. Spektra FTIR Pati Amorphophallus campanulatus

(Lestari dkk, 2016)

Gambar 2 menunjukkan spektra FTIR pati suweg murni tetapi yang diisolasi dengan menggunakan pelarut kimia (Lestari dkk; 2016). Perbedaan yang signifikan yang ada pada kedua jenis pati ini adalah pada panjang gelombang antara $3.500 \mathrm{~cm}^{-1}$ dan 1.500-500 $\mathrm{cm}^{-1}$ dimana ikatan kimia $\mathrm{PB}$ memiliki ikatan $\mathrm{O}-\mathrm{H}$ yang lebih kuat dibandingkan dengan pati yang diisolasi dengan pelarut kimia dan juga ikatan $\mathrm{C}-\mathrm{N}$ pada PB lebih kuat dari pati yang diisolasi dengan pelarut kimia. Hal ini disebabkan karena pengaruh pelarut yang digunakan sebelumnya yaitu heksena - kloroform metanol yang diperkirakan merusak struktur ikatan kimia yang ada di dalam pati tersebut. Di tinjau dari ikatan $\mathrm{O}-\mathrm{H}$, pati singkong memiliki ikatan kimia yang paling baik kemudian disusul oleh pati suweg dan kemudian pati jagung, hal ini dilihat dari bentuk peak yang simteris pada pati singkong. Pada pati jagung \% transmitasi rendah dikarenakan masih banyaknya air pada sampel jagung tersebut sehingga menyebabkan peak yang muncul tidak tajam.

SEM adalah instrumen untuk mengetahui morfologi obyek skala mikro hingga nano. Secara prinsip kerja, obyek pertama kali ditreatmen dengan emas murni untuk kemudian di masukkan ke dalam preparat mikroskop. SEM yang digunakan adalah merk FEI Inspect yang ada di Laboratorium Fisika dan Material Maju Universitas Negeri Malang.

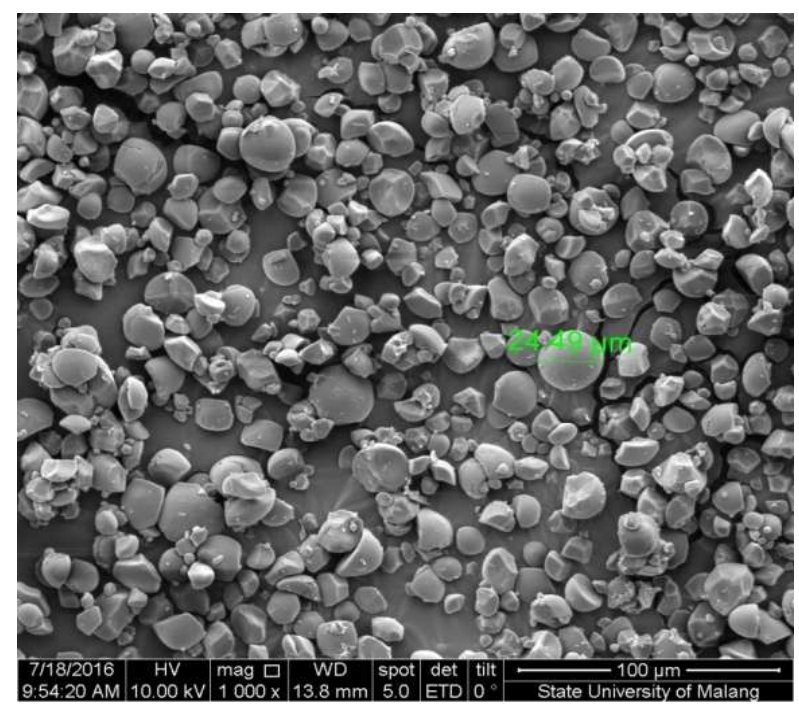

Gambar 3. Citra SEM PB.

Gambar 3 menunjukkan citra SEM untuk PB. Pada perbesaran $100 \mathrm{x}$, terlihat bahwa PB merupakan butiran butiran pati yang tidak seragam dengan diameter rata rata adalah 24,49 $\mu \mathrm{m}$. Permukaan PB tampak 
halus dan seragam serta tidak banyak seratserat yang tampak. Hal ini dikarenakan proses isolasi pati dari umbi basah yang baik. Jika dibandingkan dengan pati suweg yang diisolasi dengan menggunakan pelarut kimia yang sudah diteliti oleh Lestari dkk (2016) yang sudah ter display pada Gambar 4 terlihat bahwa ada serat - serat halus yang terlihat di sekitar butiran pati.

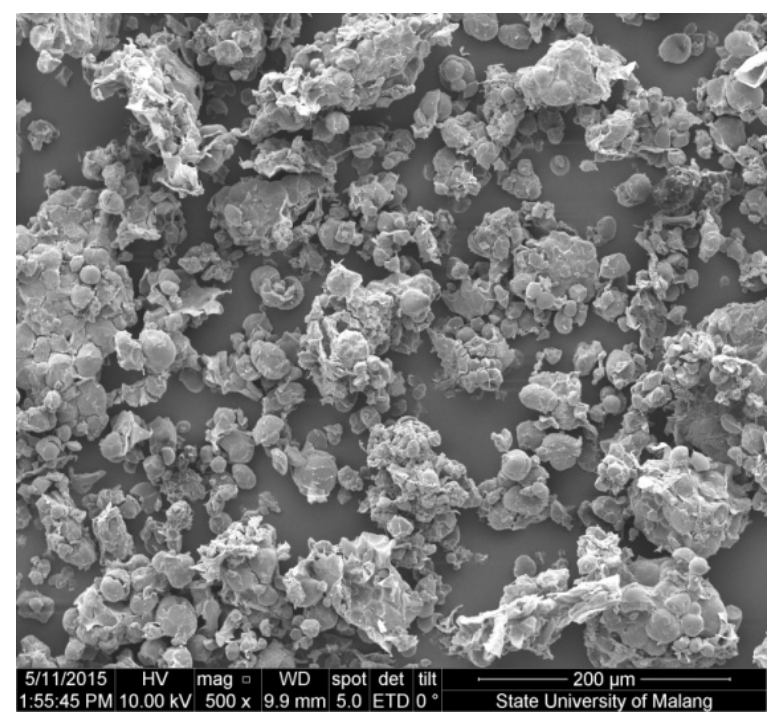

Gambar 4. Citra SEM Pati Suweg

(Lestari et al, 2016).

Gambar 5 menampilkan citra SEM yang ada pada sampel PT. Pada perbesaran $500 \mathrm{x}$ kita dapat melihat bahwa tampak adanya perubahan struktur permukaan PB menjadi lebih banyak pori - porinya seperti yang bisa dilihat dari gambar 5 bahwa ada guratanguratan halus di bagian dalam suatu butiran pati. Pada perbesaran $2.000 \mathrm{x}$ kita dapat melihat bahwa diameter rata - ratanya adalah 5,24 $\mu \mathrm{m}$. Proses sintesis PT dari PB membuat pori - pori sampel menjadi lebih kecil, hal ini diharapkan dapat mendukung kinerja adsorpsinya.

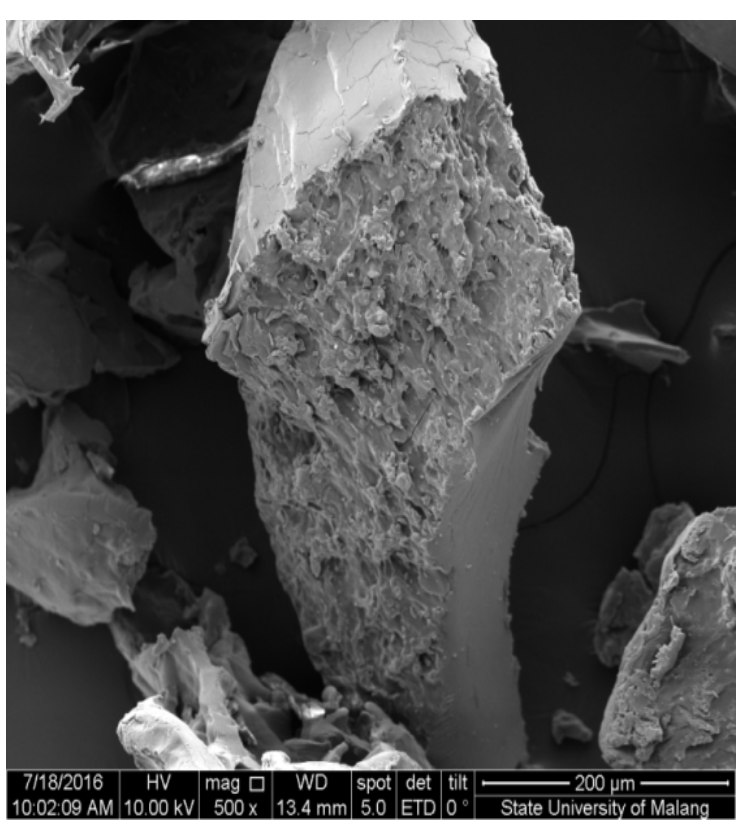

Gambar 5. Citra SEM PT.

Gambar 6 menampilkan citra SEM yang ada pada sampel PTM. Pada perbesaran 100 $\mathrm{x}$ nampak bahwa penampakan pori - pori dan ketidak aturan sampel lebih konsisten dibandingkan dengan PT. Hal ini diharapkan mampu pula menjadi salah satu pendukung kemampuan PTM dalam proses adsorpsi.

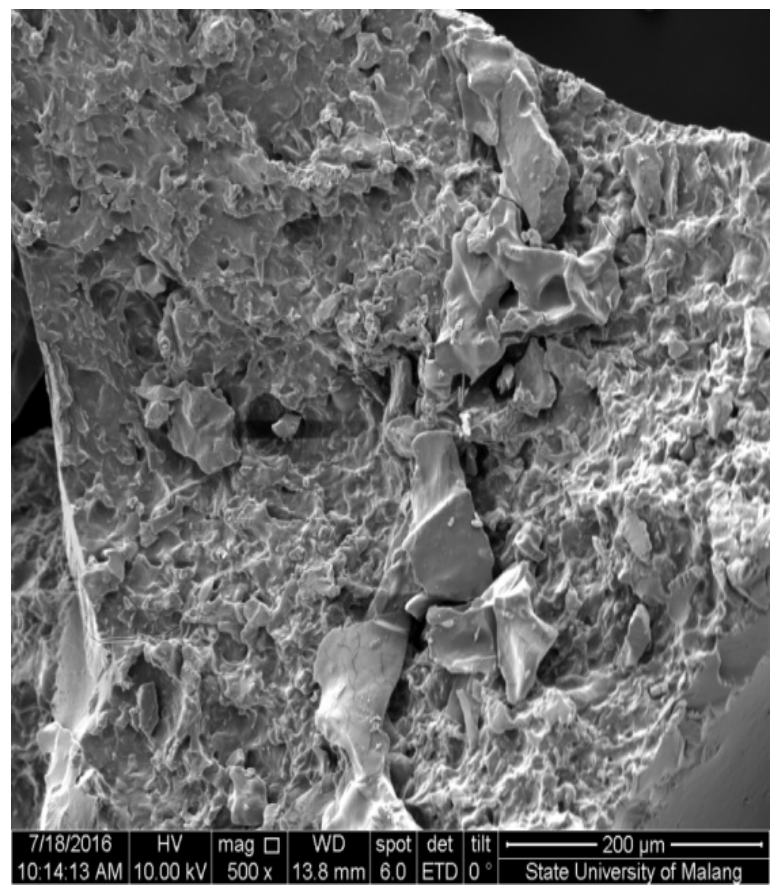

Gambar 6. Citra SEM PTM. 


\subsection{Isoterm Adsorpsi Adsorben}

Mekanisme adsorpsi $\mathrm{Pb}$ dalam beberapa jenis variasi konsentrasi limbah sintetis oleh PB, PT dan PTM dievaluasi dengan menggunakan gambar 7 yang merepresentasikan bahwa kemampuan PTM dalam mengadsorpsi $\mathrm{Pb}$ lebih baik dibandingkan PB dan PT ditinjau dari \% adsorpsi yang lebih besar dari PB dan PT.

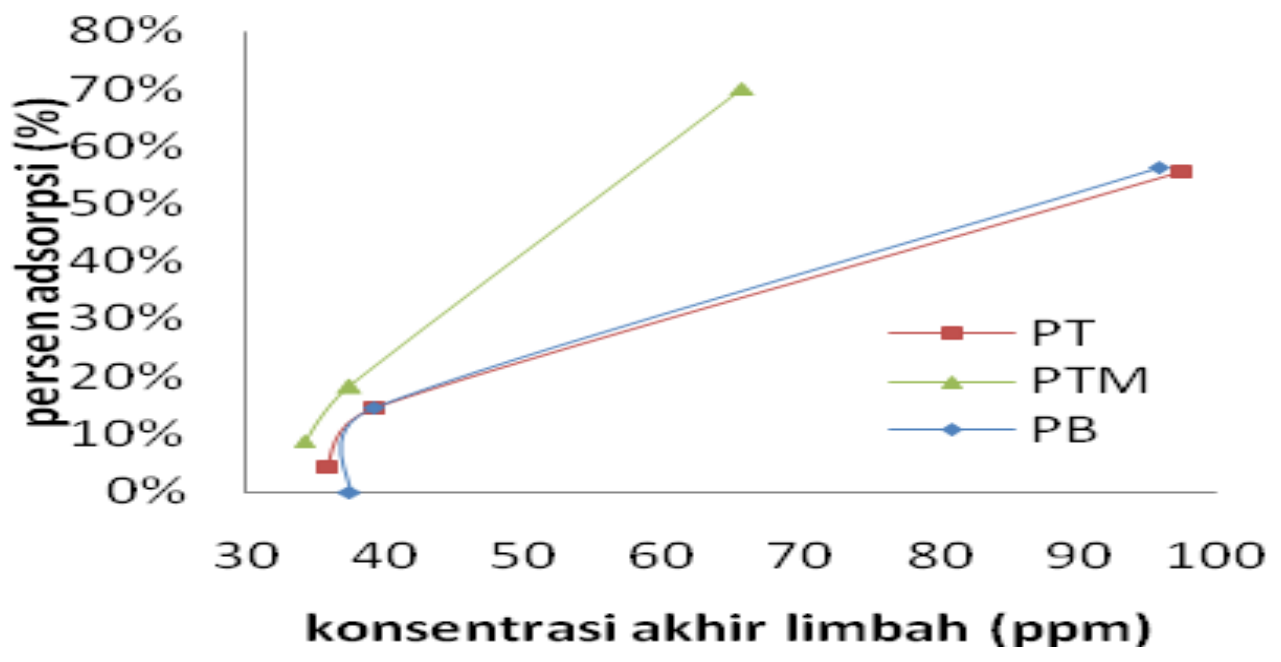

Gambar 7. Kemampuan Adsorpsi Pb pada Adsorben PB, PT dan PTM.

Karakteristik adsorpsi $\mathrm{Pb}$ pada $\mathrm{PB}, \mathrm{PTM}$ dan PTM diidentifikasi dengan beberapa persamaan isoterm adsorpsi, yaitu: Langmuir, Freundlich, Temkin dan Dubinin.

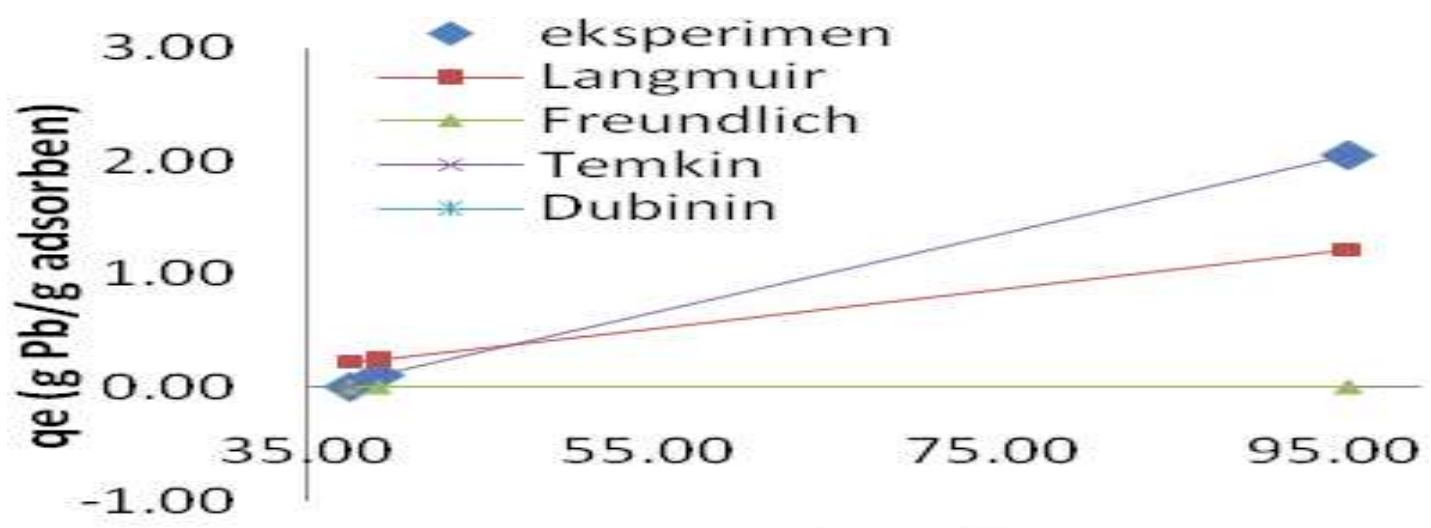

\section{Ce (ppm)}

Gambar 8. Karakterisasi Adsorpsi Pb dengan Adsorben PB. 


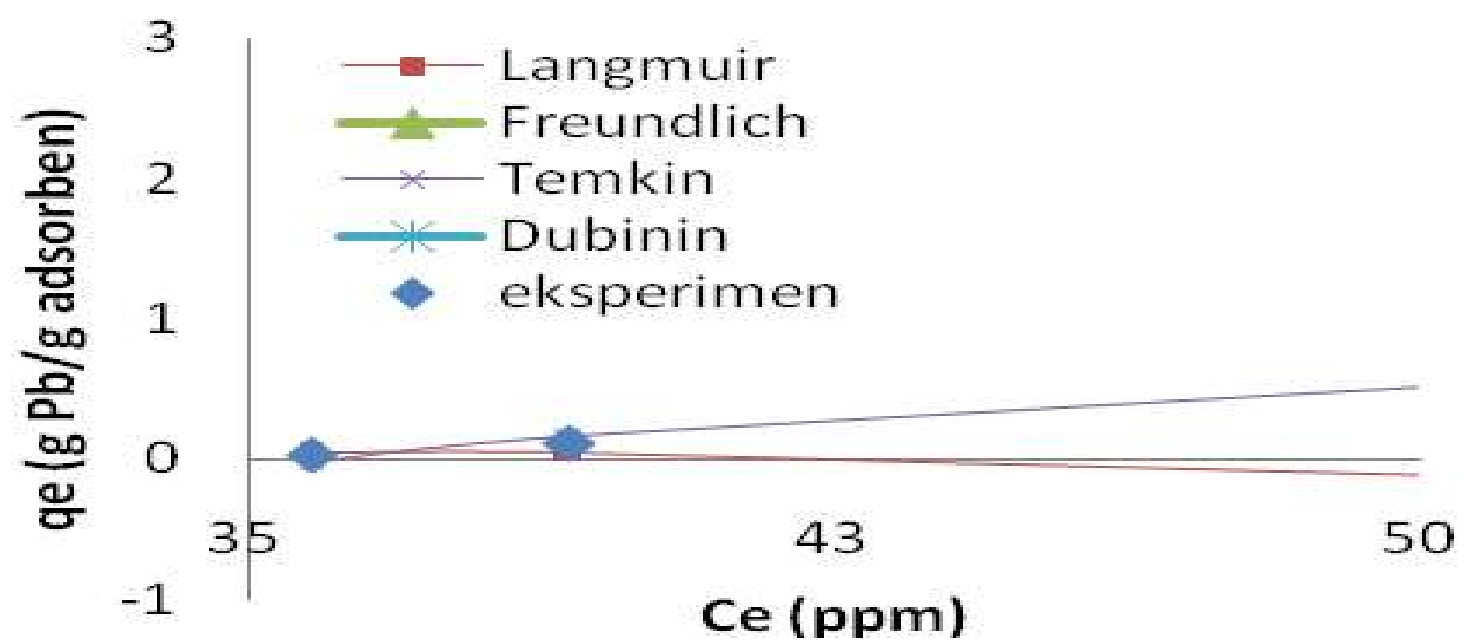

Gambar 9. Karakterisasi Adsorpsi Pb dengan Adsorben PT.

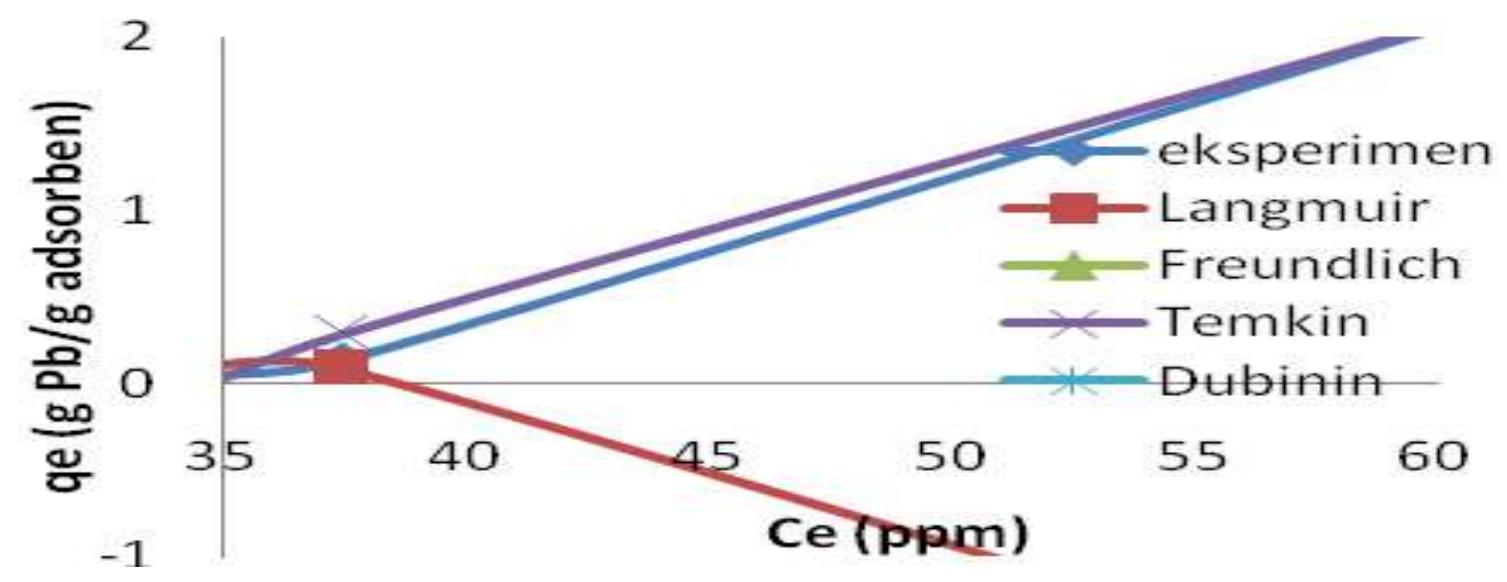

Gambar 10. Karakterisasi Adsorpsi Pb dengan Adsorben PTM.

Dari ketiga grafik pemodelan ini terlihat ini memiliki parameter adsorpsi yang akan bahwa adsorpsi $\mathrm{Pb}$ baik oleh $\mathrm{PB}$, PT dan PTM memiliki karakteristik yang sama disajikan pada tabel 1 berikut. dengan proses isoterm Temkin dimana proses

Tabel 1. Parameter Isoterm Temkin untuk Masing - Masing Adsorben

\begin{tabular}{c|c|c|c}
\hline & $\mathrm{A}_{\mathrm{T}}(\mathrm{L} / \mathrm{g})$ & $\mathrm{B}(\mathrm{J} / \mathrm{mol})$ & $\mathrm{R}^{2}$ \\
\hline PB & 0,027 & 2,181 & 0,999 \\
PT & 0,028 & 2,039 & 0,998 \\
PTM & 0,029 & 3,977 & 0,989 \\
\hline
\end{tabular}




\section{KESIMPULAN DAN SARAN}

Penelitian ini menyimpulkan bahwa pati suweg berpotensi menjadi adsorben karena memiliki karakteristik yang mirip dengan zeolit serta adsorben berbasis biomassa lainnya. Di tinjau dari ikatan kimianya, PTM adalah adsorben yang memiliki ikatan kimia $\mathrm{O}-\mathrm{H}, \mathrm{C}-\mathrm{N}$ dan $\mathrm{C}=\mathrm{O}$ yang kuat serta memiliki morfologi dan diameter pori yang lebih baik dibandingkan dengan PB dan PT.

Penelitian selanjutnya difokuskan pada aplikasi adsorben untuk mengetahui kemampuan adsorpsi dari PT, PB dan PTM pada berbagai larutan logam berat.

\section{Ucapan Terima kasih}

Penulis mengucapkan terima kasih kepada Jurusan Teknik Kimia Fakultas Teknologi Industri Universitas Islam Indonesia karena sudah membiayai riset ini lewat Hibah Penelitian Dosen Bersama Mahasiswa.

\section{DAFTAR PUSTAKA}

AYD Lestari, M Djaeni, AM Fuadi. "Amorphophallus campanulatus modified starch as adsorbent for water adsorption." Reaktor, Vol 16, pp 9-16. 2016.

DW O'Connell, C Birkinshaw dan TF O'Dwyer. "Heavy metal adsorbents prepared from the modification of cellulose: a review." Bioresource Technology, vol. 99, pp. 6709-6724. 2008.

E Harmayani, V. Aprilia dan Y. Marsono. "Characterization of glucomannan from Amorphophallus oncophyllus and its prebiotic activity in vivo." Carbohydrate Polymers, vol. 112, pp. 475-479. 2014.

$\mathrm{HN}$ Ogungbenle. "Effect of chemical modification on starch of some legume flours". Pakistan Journal of Nutrition, Vol. 6, pp. 167-171. 2007.
O Tatirat, S Charoenrein dan WL Kerr, "Physicochemical properties of extrusion-modified konjac glucomannan". Carbohydrate Polymers, vol 87, pp 1545. 2012.

PR. Chang, J. Yu, X. Ma. "Preparation of porous starch and its use as a structure directing agent for production of porous zinc oxide". Carbohydrate Polymers, vol. 83, pp. 1016-1019. 2011.

RK. Gautam, A. Mudhoo, G. Lofrano, dan MC. Chattopadhyaya. "Biomass-derived biosorbents for metal ions sequestration: Adsorbent modification and activation methods and adsorbent regeneration." Journal of Environmental Chemical Engineering, Vol 2, pp. 239259. 2014.

Stuart, Barbara. "Infrared spectroscopy: fundamentals and applications." John Wiley and Sons. 2009.

X Ma, L Xueyuan, PA Debbie, Peter RC. "Modification of porous starch for the adsorption of heavy metal ions from aqueous solution". Food Chemistry, vol 18q, pp. 133-139. 2015. 